\title{
Dynamic corrosion of refractories by $\mathrm{Na}_{2} \mathrm{CO}_{3}$
}

\author{
Yu Xiang ${ }^{1, a}$, Ying Zhao ${ }^{1, b^{*}}$, Lu Liu $^{1, \mathrm{c}}$, Zongming Zheng ${ }^{1}$,Changqing Dong ${ }^{1}$ \\ ${ }^{1}$ North China Electric Power University, Beijing, China \\ axiang_yu1991@163.com, bhaoying_1999@sohu.com, ${ }^{c}$ 381984879@qq.com
}

Keywords: dynamics, refractories, $\mathrm{Na}_{2} \mathrm{CO}_{3}$

Abstract. The corrosion of refractories by $\mathrm{Na}_{2} \mathrm{CO}_{3}$ at high temperature has become a severe issue. For a better understanding of corrosion mechanisms, this paper works out the kinetics mechanism of corrosion reaction including characteristic parameters and dynamics equation. The results provide the theoretical basis of sodium carbonate corrosion on refractories and give an evidence of the direction of corrosion resistance of refractories .

\section{Introduction}

Refractories are widely used in industries such as iron and steel,cement,and so on. However, there are severe corrosion in boilers. Therefore the scholars have studied in resistance of various refractory materials to corrosion, in order to solve the problem of corrosion.

Many researches show that refractories containing $\mathrm{Cr}_{2} \mathrm{O}_{3}$ have excellent performance in resistance to slag corrosion. Firstly, $\mathrm{Cr}_{2} \mathrm{O}_{3}$ has smaller solubility in the slag and could increase the viscosity of the molten slag, resulting in reducing chemical erosion of refractory,Secondly, increase of viscosity reduced the permeability and wettability of refractory materials and the formation of the metamorphic layer, thereby reducing flake refractory materials' structure. Refractory materials containing Cr2O3 have better performance among the basic refractory materials. But in waste incineration boiler alkali metal salts can cause severe corrosion in refractories, in addition, refractories were more prone to mechanical damage in high temperature, so that the service life of refractory material might be shorten and great hidden danger and economic losses might be happened.

\section{Experimental}

In order to have a better understanding of chromium refractory corrosion by $\mathrm{Na}_{2} \mathrm{CO}_{3}$, this paper studies the dynamic corrosion. Synchronous thermal analyzer (SDT) of the TA instrument company is provided for the experimental and its type is SDT-Q600. The samples will be analyzed with differential scanning calorimetry (DSC) and thermogravimetric analysis (TGA) at the same time. Its test temperature range from room temperature to $1500{ }^{\circ} \mathrm{C}$ and its measurable parameters include material internal change, heat flux, weight change. Raw materials are reacted at the ratio of 1:1 and the heating rate of $30^{\circ} \mathrm{C} / \mathrm{min}$.

For isothermal reaction, the reaction rate is only a function of time under the certain reaction conditions. Thus, the study make the reaction rate of the reaction time under different reaction time in the dynamic equation of the form of linear according to the following table, resulting in the kinetic model and kinetic parameters. 
Table 1 kinetic model

\begin{tabular}{|c|c|c|}
\hline functions & mechanism & Integral form \\
\hline G-B & $\begin{array}{l}\text { Three dimensional diffusion, } \\
\text { spherical symmetric, } 3 \mathrm{~d}, \mathrm{D} 4, \\
\text { deceleration } \alpha \text { curve }\end{array}$ & $\underset{2 / 3}{(1-2 / 3 \alpha)}-(1-\alpha)$ \\
\hline Jander & $3 \mathrm{~d}, \mathrm{D} 3$, reduction of $\alpha$ curve, $\mathrm{n}=2$ & {$\left[1-(1-\alpha)^{1 / 3}\right]^{2}$} \\
\hline Jander & $\begin{array}{l}\text { Three dimensional diffusion, } 3 \mathrm{~d}, \mathrm{n}= \\
1 / 2\end{array}$ & {$\left[1-(1-\alpha)^{1 / 3}\right]^{1 / 2}$} \\
\hline Jander & $\begin{array}{l}\text { The two-dimensional diffusion, } 2 \mathrm{~d} \text {, } \\
\qquad \mathrm{n}=1 / 2\end{array}$ & {$\left[1-(1-\alpha)^{1 / 2}\right]^{1 / 2}$} \\
\hline Avrami-Erofeev & $\begin{array}{l}\text { Random nucleation and subsequent } \\
\text { growth, } \\
\text { A2, s-shaped } \alpha \text { curve. } \mathrm{N}=1 / 2, \mathrm{~m}=2 \\
\text { Random nucleation and subsequent }\end{array}$ & {$[-\ln (1-\alpha)]^{1 / 2}$} \\
\hline Avrami-Erofeev & $\begin{array}{l}\text { growth, } \\
\text { A3, s-shaped } \alpha \text { curve, } n=1 / 3, \mathrm{~m}=3\end{array}$ & {$[-\ln (1-\alpha)]^{1 / 3}$} \\
\hline Avrami-Erofeev & $\begin{array}{l}\text { Random nucleation and subsequent } \\
\text { growth. } \mathrm{N}=4\end{array}$ & {$[-\ln (1-\alpha)]^{4}$} \\
\hline Avrami-Erofeev & $\begin{array}{l}\text { Random nucleation and subsequent } \\
\text { growth, A4, s-shaped curve of } \alpha, \mathrm{n}=1 / 4, \\
\mathrm{~m}=4\end{array}$ & {$[-\ln (1-\alpha)]^{1 / 4}$} \\
\hline Avrami-Erofeev & $\begin{array}{l}\text { Random nucleation and subsequent } \\
\text { growth, } \mathrm{n}=2\end{array}$ & {$[-\ln (1-\alpha)]^{2}$} \\
\hline Avrami-Erofeev & $\begin{array}{l}\text { Random nucleation and subsequent } \\
\text { growth, } n=3\end{array}$ & {$[-\ln (1-\alpha)]^{3}$} \\
\hline order reaction & $n=3$ & $1-(1-\alpha)^{3}$ \\
\hline order reaction & $\mathrm{n}=2$ & $1-(1-\alpha)^{2}$ \\
\hline order reaction & $\mathrm{n}=4$ & $1-(1-\alpha)^{4}$ \\
\hline order reaction & $\mathrm{n}=1 / 4$ & $1-(1-\alpha)^{1 / 4}$ \\
\hline Mample Power & $\begin{array}{c}\text { Phase boundary reaction }(\mathrm{d}), \mathrm{R} 1, \mathrm{n}= \\
1\end{array}$ & $\alpha$ \\
\hline Mample Power & $\mathrm{n}=3 / 2$ & $\alpha^{3 / 2}$ \\
\hline Mample Power & $\mathrm{n}=1 / 2$ & $\alpha^{1 / 2}$ \\
\hline Mample Power & $\mathrm{n}=1 / 3$ & $\alpha^{1 / 3}$ \\
\hline Mample Power & $\mathrm{n}=1 / 4$ & $\alpha^{1 / 4}$ \\
\hline
\end{tabular}

\section{Results and Discussion}

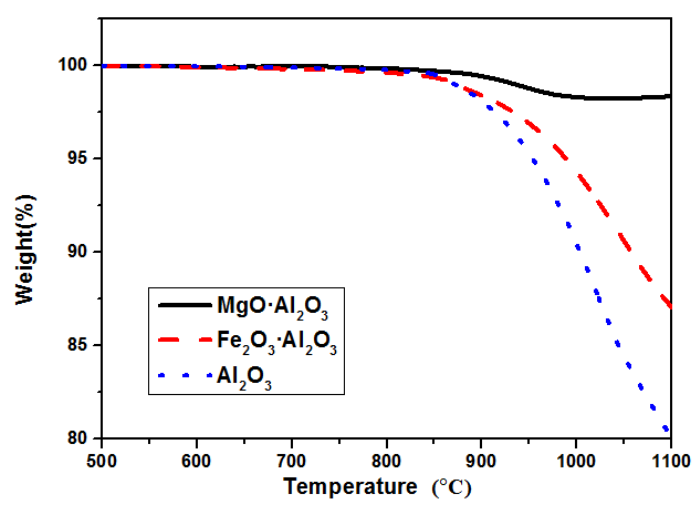

Fig. 1 thermogravimetric curves of reactions of $\mathrm{Al}_{2} \mathrm{O}_{3}$-spinel with $\mathrm{Na}_{2} \mathrm{CO}_{3}$ 


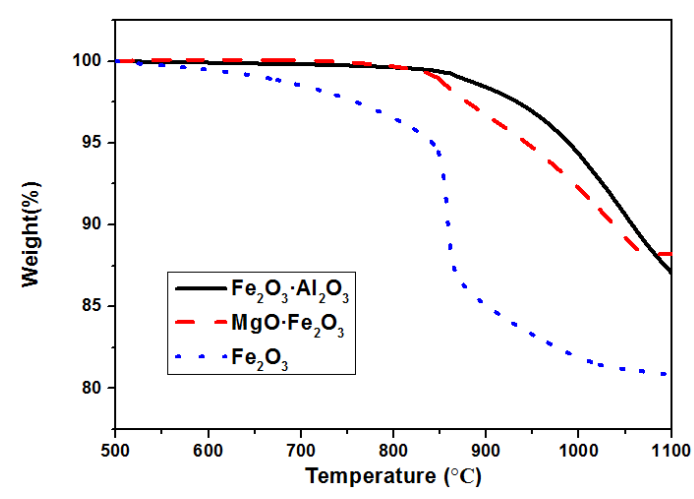

Fig.2 thermogravimetric curves of reactions of $\mathrm{Fe}_{2} \mathrm{O}_{3}$-spinel with $\mathrm{Na}_{2} \mathrm{CO}_{3}$

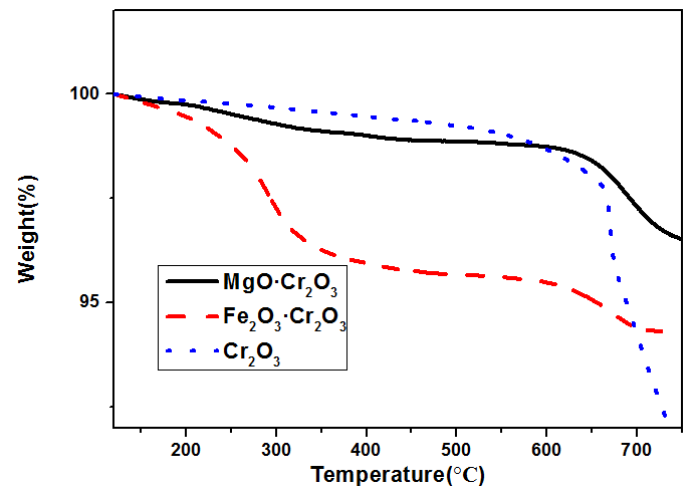

Fig. 3 thermogravimetric curves of reactions of $\mathrm{Cr}_{2} \mathrm{O}_{3}$-spinel with $\mathrm{Na}_{2} \mathrm{CO}_{3}$

Fig. 1 despicts that the reaction of $\mathrm{Al}_{2} \mathrm{O}_{3}$ with $\mathrm{Na}_{2} \mathrm{CO}_{3}$ at the heating rate of $30^{\circ} \mathrm{C} / \mathrm{min}$ won't reach to reaction equilibrium when up to $1200{ }^{\circ} \mathrm{C}$. while $\mathrm{Al}_{2} \mathrm{O}_{3}$ began to react with $\mathrm{Na}_{2} \mathrm{CO}_{3}$ after $800{ }^{\circ} \mathrm{C}$ and the reaction speed up at $950{ }^{\circ} \mathrm{C}$. Magnesium aluminate spinel reactes with $\mathrm{Na}_{2} \mathrm{CO}_{3}$ at above $850{ }^{\circ} \mathrm{C}$ and when at $1200^{\circ} \mathrm{C}$ the reaction is accelerated but not balance. The reaction of Hercynite with $\mathrm{Na}_{2} \mathrm{CO}_{3}$ began at around $800{ }^{\circ} \mathrm{C}$, accelerating rapidly with rising temperature. What's more, the reaction get the maximum reaction rate at $1048{ }^{\circ} \mathrm{C}$ and is not balanced when $1200^{\circ} \mathrm{C}$.

Fig. 2 shows the reaction of $\mathrm{Fe}_{2} \mathrm{O}_{3}$ with $\mathrm{Na}_{2} \mathrm{CO}_{3}$ is lower than the reaction of $\mathrm{Na}_{2} \mathrm{CO}_{3}$ with magnesium spinel reaction in temperature, speeding up at $700{ }^{\circ} \mathrm{C}$ and becoming a negative reaction between $850^{\circ} \mathrm{C}$ to $860^{\circ} \mathrm{C}$. The products of Magnesia spinel reacting with $\mathrm{Na}_{2} \mathrm{CO}_{3}$ under the condition of high temperature are magnesium and iron material. So thermogravimetric curve of weightlessness is caused by releasing $\mathrm{CO}_{2}$ in the process of formating acid sodium and the weightlessness rate is related to reflecting the generated rate of sodium ferrate. magnesia spinel has the obvious reaction with $\mathrm{Na}_{2} \mathrm{CO}_{3}$ until around $800{ }^{\circ} \mathrm{C}$ and at about $1000{ }^{\circ} \mathrm{C}$ reach equilibrium.

Fig.3 illustrates the reaction of iron chromium spinel with $\mathrm{Na}_{2} \mathrm{CO}_{3}$ starts below $600^{\circ} \mathrm{C}$ and balances out at around $750{ }^{\circ} \mathrm{C}$ at the heating rate of $30^{\circ} \mathrm{C} / \mathrm{min}$. Thermogravimetric curve shows that the reaction when $700{ }^{\circ} \mathrm{C}$ has been completed by more than $90 \%$. reaction of Chrome oxide with $\mathrm{Na}_{2} \mathrm{CO}_{3}$ begin at about $600{ }^{\circ} \mathrm{C}$ and level off when $1000^{\circ} \mathrm{C}$. Furthermore, reaction quickened at $680{ }^{\circ} \mathrm{C}$ and is more easy to take place than that of $\mathrm{Fe}_{2} \mathrm{O}_{3}$ with $\mathrm{Na}_{2} \mathrm{CO}_{3}$. Reaction of Magnesium chromium spinel with $\mathrm{Na}_{2} \mathrm{CO}_{3}$ speed when $600^{\circ} \mathrm{C}$ and is basically reach equilibrium when $800{ }^{\circ} \mathrm{C}$.

According to the methods of studying kinetics under the condition of non-isothermal, reaction rates at different temperature are plugged into mechanism functions $(F(\alpha))$ in the table below and are resolved by linear regression method. Through the analysis of the linear correlation coefficient and the sum of squared residuals, there was a good linear relationship between $\operatorname{LnF}(\alpha) / \mathrm{T}^{2}$ and $1 / \mathrm{T}$ in process of $\mathrm{Na}_{2} \mathrm{CO}_{3}$ reacting with $\mathrm{Fe}_{2} \mathrm{O}_{3}$. Its process is in line with the Avrami - Erofeev model and its is random nucleation and growth. The integral form is $[-\ln (1-\alpha)]^{4}$. The formula of $F(\alpha)$ is in the following:

$$
F(\alpha)=\int_{0}^{\alpha} \frac{d \alpha}{f(\alpha)}=\frac{A R T^{2}}{\beta E}\left(1-\frac{2 R T}{E}\right) e^{-\frac{E}{R T}} .
$$


The dynamic results of corrosion reactions are in the following table.

Table 2: Dynamic analysis

\begin{tabular}{|c|c|c|c|}
\hline Materials & $\mathrm{E}(\mathrm{kJ} / \mathrm{m}$ & $\mathrm{A}\left(\min ^{-1}\right.$ & Kinetic Equations \\
\hline $\mathrm{Fe}_{2} \mathrm{O}_{3}$ & 414.92 & $\begin{array}{c}6.08 \times 1 \\
0^{43}\end{array}$ & $\begin{array}{c}\mathrm{d} \alpha / \mathrm{dT}=1.52 \times 10^{43} \exp (-49.90 \times 1 / \mathrm{T})(1-\alpha)[-\ln (1 \\
-\alpha)]^{-3}\end{array}$ \\
\hline $\mathrm{Cr}_{2} \mathrm{O}_{3}$ & 191.45 & $\begin{array}{c}2.54 \times 1 \\
0^{15}\end{array}$ & $\begin{array}{c}\mathrm{d} \alpha / \mathrm{dT}=6.35 \times 10^{14} \exp (-23.03 \times 1 / \mathrm{T})(1-\alpha)[-\ln (1 \\
-\alpha)]^{-3}\end{array}$ \\
\hline $\mathrm{Al}_{2} \mathrm{O}_{3}$ & 849.75 & $\begin{array}{c}4.40 \times 1 \\
0^{31}\end{array}$ & $\mathrm{~d} \alpha / \mathrm{dT}=1.10 \times 10^{31} \exp (-102.20 \times 1 / \mathrm{T})(1-\alpha)[-\ln ($ \\
\hline $\begin{array}{l}\text { Iron chromium } \\
\text { spinel }\end{array}$ & 225.12 & $\begin{array}{c}2.26 \times 1 \\
0^{10}\end{array}$ & $\begin{array}{c}\mathrm{d} \alpha / \mathrm{dT}=5.65 \times 10^{9} \exp (-27.08 \times 1 / \mathrm{T})(1-\alpha)[-\ln (1- \\
\alpha)]^{-3}\end{array}$ \\
\hline $\begin{array}{c}\text { Magnesium } \\
\text { chromium spinel }\end{array}$ & 460.15 & $\begin{array}{c}1.13 \times 1 \\
0^{23}\end{array}$ & $\begin{array}{c}\mathrm{d} \alpha / \mathrm{dT}=2.83 \times 10^{22} \exp (-55.35 \times 1 / \mathrm{T})(1-\alpha)[-\ln (1 \\
-\alpha)]^{-3}\end{array}$ \\
\hline hercynite & 672.81 & $\begin{array}{c}3.97 \times 1 \\
0^{21}\end{array}$ & $\begin{array}{c}\mathrm{d} \alpha / \mathrm{dT}=9.93 \times 10^{20} \exp (-80.91 \times 1 / \mathrm{T})(1-\alpha)[-\ln (1 \\
-\alpha)]^{-3}\end{array}$ \\
\hline $\begin{array}{l}\text { Iron magnesia } \\
\text { spinel }\end{array}$ & 905.75 & $\begin{array}{c}5.22 \times 1 \\
0^{36}\end{array}$ & $\begin{array}{c}\mathrm{d} \alpha / \mathrm{dT}=1.31 \times 10^{36} \exp (-108.93 \times 1 / \mathrm{T})(1-\alpha)[-\ln ( \\
1-\alpha)]^{-3}\end{array}$ \\
\hline $\begin{array}{c}\text { Magnesium } \\
\text { aluminate spinel }\end{array}$ & $\begin{array}{c}1328.4 \\
0\end{array}$ & $\begin{array}{c}5.75 \times 1 \\
0^{53}\end{array}$ & $\mathrm{~d} \alpha / \mathrm{dT}=1.44 \times 10^{53} \exp (-159.76 \times 1 / \mathrm{T})(1-\alpha)[-\ln ($ \\
\hline
\end{tabular}

\section{Conclusion}

Integral method is used to deal with thermogravimetric experiments data. Through linear regression method we know that the reactions of refractories with $\mathrm{Na}_{2} \mathrm{CO}_{3}$ are all in line with the Avrami - Erofeev model. In addition, the mechanism is random nucleation and growth and the integral form is $[-\ln (1-\alpha)] 4$. The characteristic parameters of reactions are obtained at the heating rate of $30^{\circ} \mathrm{C} / \mathrm{min}$. Reactions with $\mathrm{Na}_{2} \mathrm{CO}_{3}$ are sorted alphabetically by activation energy as follows: $\mathrm{Cr}_{2} \mathrm{O}_{3}<$ iron chromium spinel $<\mathrm{Fe}_{2} \mathrm{O}_{3}<$ magnesium, chromium spinel $<$ hercynite $<\mathrm{Al}_{2} \mathrm{O}_{3}<$ alumina magnesia spinel $<$ magnesium aluminate spinel. Reaction kinetics equations are as follows:

$$
\mathrm{d} \alpha / \mathrm{dT}=1 / 4 \mathrm{~A} \exp (-\mathrm{E} / \mathrm{RT})(1-\alpha)[-\ln (1-\alpha)]^{-3}
$$

\section{Acknowledgement}

The authors thank the financial support for this work provided by the National Science and Technology Support Program(2013BAG25B03), Beijing Higher Education Young Elite Teacher Project (YETP0712), the Fundamental Research Funds for the Central Universities (2015MS20).

\section{References}

[1]Yuejin Qian,Haijun Ren. The Application and Foreground of Refractories with Chromite[J]. Journal of Luoyang Technology College,2007,05:6-9.

[2]Li Zhang. Current Research Situation of Refractories for Waste Incinerator[J]. Industrial Furnace,2009,06:40-44.

[3]Mingzhen Zhao, Jin Liang. Study on refractory material and its development in China. Journal of the Graduates Sun Yat-Sen University:Natural Sciences and Medicine, 2012, 33(4): 17-24.

[4]Dianli Xu. Prospect of the development of refractory industry[J]. Seminar on the development strategy of the national refractory raw materials in the new situation,2014.

[5]Zuoshu Sun, Yan Zhang. Corrosion of $\mathrm{Al}_{2} \mathrm{O}_{3} / \mathrm{CaO}$ on high alumina refractories during the temperature cycle .Refractories \& Lime, 2008 (4). 
[6]Ming Xia, Experimental study on corrosion reaction of Mullite/Corundum refractories and alkaline sediments.Refractories \& Lime,2014,04:55-61.

[7] Jian Hou, Jue Fang, Yanping Feng, Guosong Shi. Erosion of refractory by the ultra-high alkalinity slag produced in smelting ores from Guangxi [J]. Southern Metals,2009,02:28-30.

[8]Jinglin Liu. Application of $\mathrm{MgO}-\mathrm{C}$ refractory materials with alkaline[J].Refractories\& Lime, 2008,03:16-20.

[9]Rong Quan. Erosion of sodium and potassium on refractory materials [J]. Refractories \& Lime,2012,01:43-47.

[10]Pena P, Criado E, Bakali J J, et al. Dynamic corrosion of Al2O3-ZrO2-SiO2 and $\mathrm{Cr} 2 \mathrm{O} 3$-containing refractories by molten frits. Part II: Microstructural study[J]. Journal of the European Ceramic Society, 2011, 31(5): 705-714.

[11]Prigent P, Bouchetou M L, Poirier J. Andalusite: An amazing refractory raw material with excellent corrosion resistance to sodium vapours[J]. Ceramics International, 2011, 37(7): 2287-2296.

[12]Stjernberg J, Lindblom B, Wikström J, et al. Microstructural characterization of alkali metal mediated high temperature reactions in mullite based refractories[J]. Ceramics international, 2010, 36(2): 733-740.

[13]R. Farris, J. Allen, Aluminous refractories - alkali reactions, Iron and Steel Engineering 50 (2) (1973) 67-74.

[14]Yong Xu. Study of reaction between Mullite/Corundum refractories and alkaline sediments . Refractories \& Lime, 2013, 5: 013.

[15]Bläsing M, Schaafhausen S, Müller M. Investigation of alkali induced corrosion of SiC filter candles at high temperature, in gasification environment[J]. Journal of the European Ceramic Society, 2014, 34(4): 1041-1044.

[16]Prigent P, Bouchetou M L, Poirier J, et al. Corrosion of oxide bonded silicon carbide refractories by molten salts in solid waste-to-energy facilities[J]. Ceramics International, 2012, 38(7): 5643-5649. 